\title{
Saxicolous Bryophytes of an Ordovician Dolomite Escarpment in Interlake Manitoba, with New Species Records for the Province
}

\author{
RICHARD T. CANERS \\ 442 Earth Sciences Building, Department of Renewable Resources, University of Alberta, Edmonton, Alberta T6G 2E3 Canada; \\ email: rcaners@ualberta.ca
}

Caners, Richard T. 2011. Saxicolous bryophytes of an Ordovician dolomite escarpment in Interlake Manitoba, with new species records for the province. Canadian Field-Naturalist 125(4): 327-337.

An assessment of bryophyte species growing on an Ordovician dolomite escarpment in the Interlake region of Manitoba known as Marble Ridge revealed a diverse flora composed mostly of circumboreal floristic elements. Two liverwort families (including three species) and four moss species are reported for Manitoba for the first time: the liverworts Athalamia hyalina (Sommert.) Hatt. (Cleveaceae), Mannia fragrans (Balbis) Frye et Clark (Aytoniaceae), and Mannia sibirica (K. Müll.) Frye et Clark (Aytoniaceae) and the mosses Brachythecium collinum (Schleich. ex C. Müll.) Schimp. in B.S.G., Grimmia teretinervis Limpr., Schistidium frigidum H. H. Blom, and Seligeria donniana (Sm.) C. Müll. An annotated summary of these and other bryophyte species documented at the site is provided. The diversity of encountered bryophytes can mostly be attributed to the moist and shaded microclimatic conditions on the escarpment and the large number of microhabitats the escarpment supports. This study represents one of few accounts of bryophytes in the region and highlights the importance of this particular geologic formation in supporting a number of species that are expected to be regionally uncommon.

Key Words: Athalamia hyalina, Brachythecium collinum, bryophyte, circumboreal, floristic affinity, Grimmia teretinervis, Interlake, life form, liverwort, Manitoba, Mannia fragrans, Mannia sibirica, Marble Ridge, moss, phytogeography, Schistidium frigidum, Seligeria donniana.

A geologic formation in the Interlake region of south-central Manitoba was documented in terms of its bryophyte diversity, providing one of the first accounts of bryophytes in this part of the province. The formation is referred to as Marble Ridge on topographic maps and represents an impressive escarpment of Upper Ordovician dolomite. The bedrock at the site is part of an outcrop belt of Paleozoic rocks in southwestern Manitoba that extends from Winnipeg and Garson through the Interlake and Dawson Bay regions to the Precambrian Shield from Athapapuskow Lake to Ponton (Bannatyne 1988). Topographic relief in the Interlake is generally low (Bannatyne 1988; Land Resource Unit 1999), making Marble Ridge a conspicuous and important habitat for a number of bryophytes. Although other inland escarpments of varying sizes are found in the region, they are infrequent and are considered to be smaller than Marble Ridge (Nature Conservancy of Canada, Manitoba Region, personal communication, 2 February 2012). Documenting species diversity at the site is regarded as an important first step in understanding bryophyte occurrences in the region and recognizing issues related to their conservation.

Under the appropriate growing conditions, calcareous rock formations are known to support a number of characteristic bryophyte species, especially calciphiles (Robinson and Wells 1956; Foote 1966; Crum and Anderson 1981; Haig et al. 2000). Several features of Marble Ridge, including its large size (in relation to other geologic features in the region), variety of microhabitats, bedrock chemistry, and mesic habitat conditions, suggested before this study that it had the capacity to harbour a substantial bryophyte flora. Indeed, Marble Ridge has already been shown to host a number of provincially rare vascular plant species, including Cypripedium arietinum Ait. f. (Ram's Head Lady'sslipper), Pellaea gastonyi Windham (Gastony's Cliffbrake), Pellaea glabella ssp. occidentalis (E. Nels.) Windham (Western Dwarf Cliffbrake), and Selaginella densa Rydb. (Prairie Spikemoss) (Manitoba Association of Plant Biologists, personal communication, 6 January 2011; Manitoba Conservation, personal communication, 12 October 2011).

Objectives of this study were 1) to document the occurrence of moss and liverwort species on Marble Ridge, 2) to characterize the flora of the escarpment in terms of its floristic affinity, and 3) to identify the most important factors likely to affect the persistence of bryophytes at the site.

\section{Methods and Study Area \\ Study area}

Marble Ridge is located approximately $150 \mathrm{~km}$ north of Winnipeg, Manitoba, in the Rural Municipality of Fisher, between the towns of Fisher Branch and Hodgson (Figure $\left.1 ; 51^{\circ} 11^{\prime} \mathrm{N}, 97^{\circ} 37^{\prime} \mathrm{W}\right)$. The area lies within the Interlake region of the province in close proximity to both Lake Manitoba and Lake Winnipeg. Marble Ridge extends for several hundred metres and rises up to $5.1 \mathrm{~m}$ in elevation above the adjacent landscape (Figure 2), providing a large surface area for bryophyte colonization. The escarpment is oriented from 


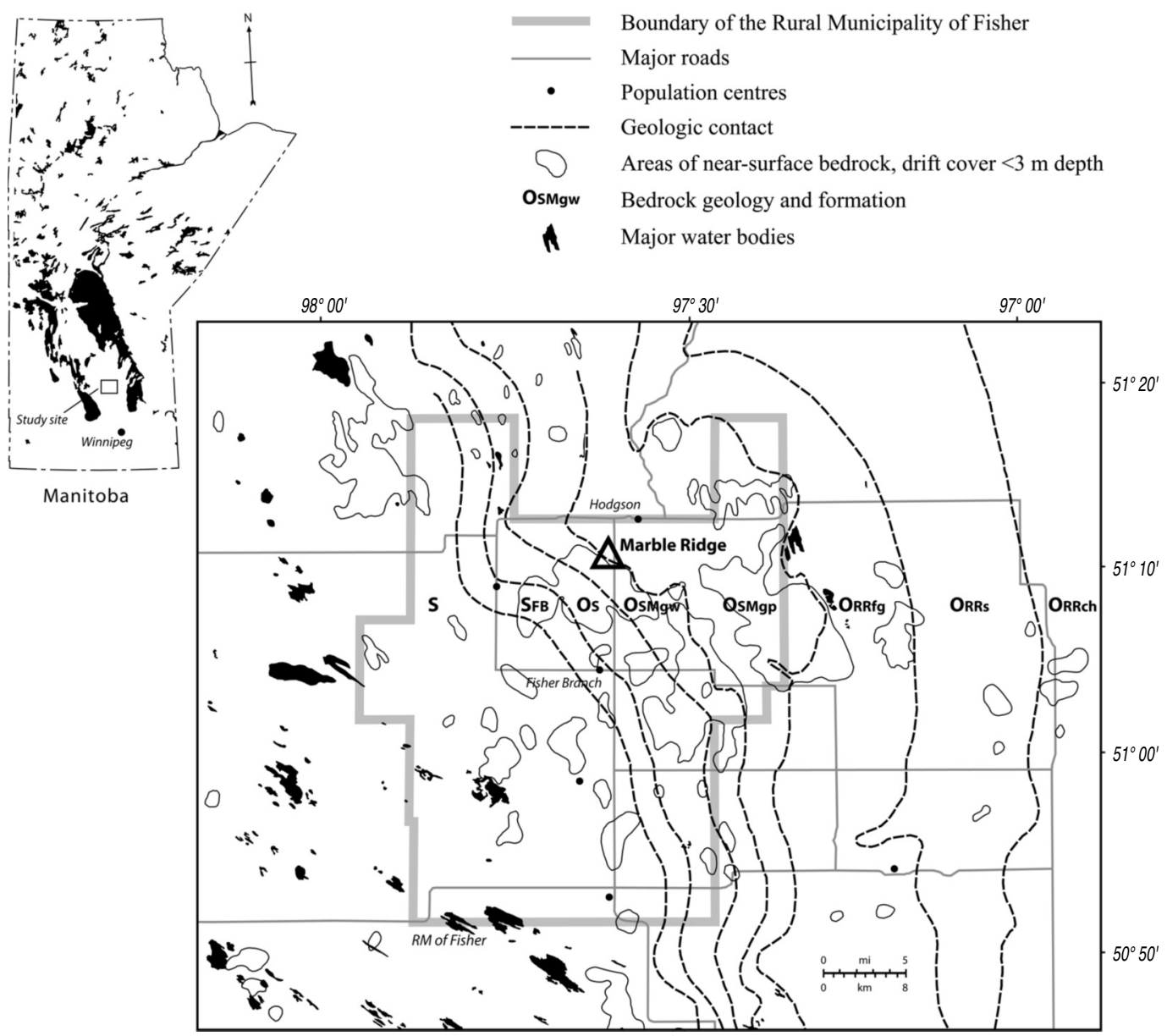

FIGURE 1. Location of the study site in Manitoba, with surrounding bedrock stratigraphy (adapted from Bannatyne 1988). The following codes refer to exposed surficial bedrock formations. S: Silurian, Interlake Group; SFB: Silurian, Fisher Branch Formation; Os: Ordovician and Silurian, Stonewall Formation; Osmgw: Ordovician, Stony Mountain Formation, Gunton Member and Williams Member; Osmgp: Ordovician, Stony Mountain Formation, Gunn Member and Penitentiary Member; OrRfg: Ordovician, Red River Formation, Fort Garry Member; OrRs: Ordovician, Red River Formation, Selkirk Member; ORRch: Ordovician, Red River Formation, Cat Head Member.

the north-northwest to the south-southeast with an eastto northeast-facing aspect, and it is sheltered to the east by boreal forest of mixed tree species. Populus tremuloides Michx. (Trembling Aspen) and Betula papyrifera Marsh. (Paper Birch) are found immediately adjacent to the rock face, and Picea glauca (Moench) Voss (White Spruce) becomes more abundant at slightly lower elevations in nearby areas to the east. The escarpment forms the eastern boundary of an adjacent alvar habitat, broadly defined as prairie vegetation over limestone or dolostone plain, with thin to absent soils (Reschke et al. 1999*). Alvars are considered to be uncommon worldwide and rare in Canada. There are few alvars west of Ontario in North America, the majority being concentrated in the Great Lakes region and in parts of Québec (Reschke et al. 1999*).
Marble Ridge lies within the Interlake Plain Ecoregion of the Boreal Plains Ecozone (Ecological Stratification Working Group 1995). This ecoregion extends northwest from the southeastern corner of Manitoba to the Manitoba-Saskatchewan border north of the Porcupine Hills, and it is characterized by a broadleafdominated forest that marks the southern limit of the closed-crown boreal forest and the northern extent of arable agriculture (Ecological Stratification Working Group 1995). The climate is sub-humid low-boreal, characterized by warm summers and cold winters (Ecological Stratification Working Group 1995). In the vicinity of Marble Ridge, the mean annual daily temperature is $1.5^{\circ} \mathrm{C}$ and the mean total annual precipitation is $511.9 \mathrm{~mm}$, with approximately $80 \%$ falling as rain (Table 1; Environment Canada 2011*). 

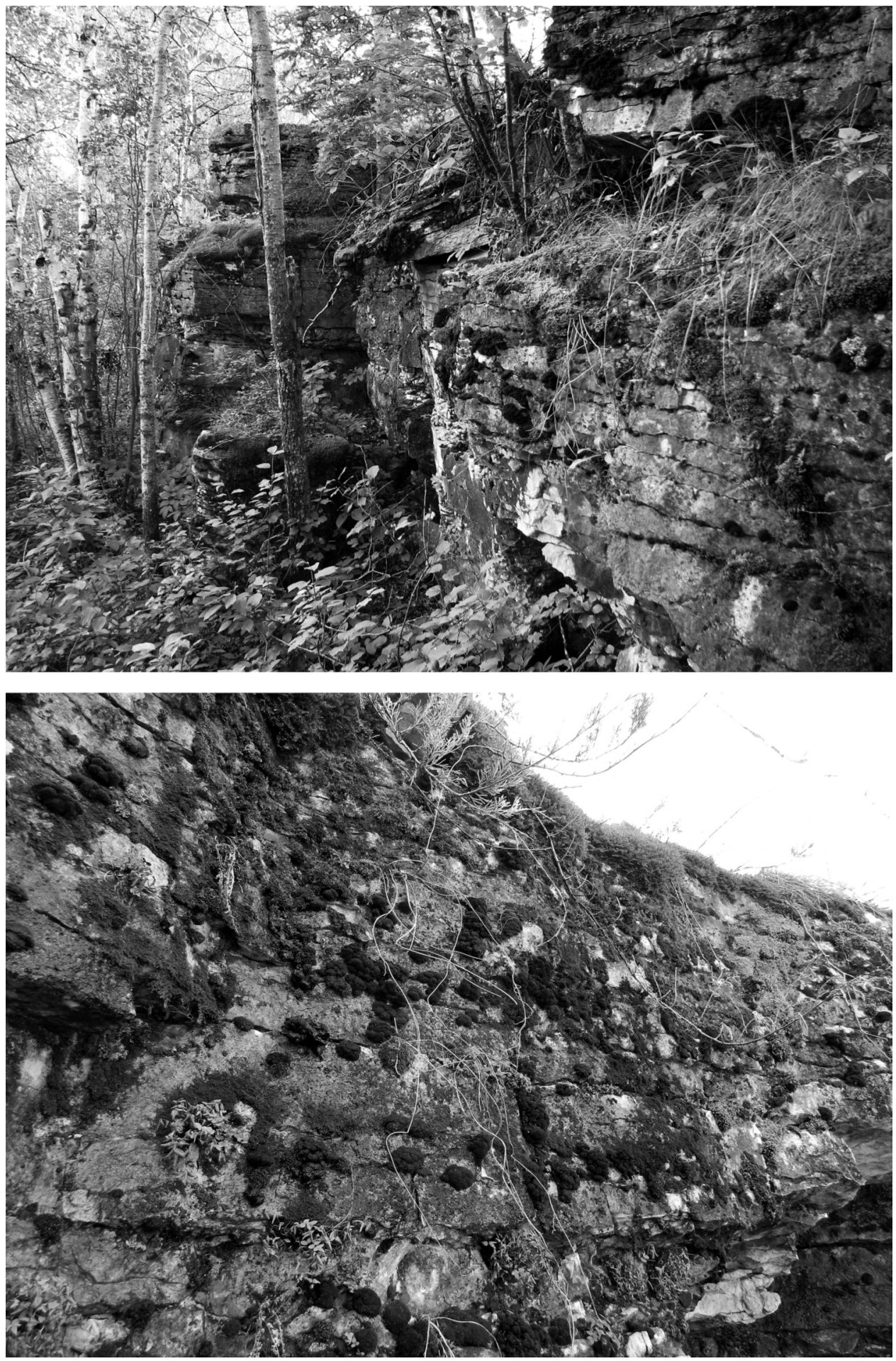

FIGURE 2. Marble Ridge. In both photographs, the escarpment is facing approximately east. Top: portion of the escarpment with a canopy cover of Trembling Aspen and Paper Birch. Bottom: a mesic rock face supporting numerous large colonies of the uncommon moss Grimmia teretinervis. 
Surficial and bedrock geology

Marble Ridge is situated within the Fisher River Plain, a level to gently undulating area of shallow lacustrine materials underlain by glacial till (Groom 1985; Land Resource Unit 1999). Local relief is generally characterized by slopes of $0-2 \%$, except where higher till, beach ridges, and rock outcrops are $2-5 \%$ above the plain (Land Resource Unit 1999). Surficial materials are predominantly shallow calcareous till over bedrock, lacustrine deposits, and organic soils, with glaciofluvial deposits of sand and gravel (Land Resource Unit 1999).

The exposed bedrock at Marble Ridge belongs to the Gunton Member of the Stony Mountain Formation (Bannatyne 1988; Gaywood Matile, Manitoba Innovation, Energy and Mines, personal communication, 28 July 2011). The exposed bedrock maintains a relatively uniform lithology, consisting of pale yellowishbrown, faintly mottled, very finely crystalline, dense, sparsely fossiliferous dolomite and showing a thin nodular bedding (Glass 1990). The Gunton Member has a maximum thickness of $11 \mathrm{~m}$ and is economically the most important of the Stony Mountain Formation, being the major source of crushed stone aggregate for the Winnipeg and southern Interlake region (Bannatyne 1988; Norford et al. 1994). Several quarry leases are currently held on Crown lands immediately west of Marble Ridge (Government of Manitoba 2011*).

The Ordovician to Lower Devonian rocks that are currently preserved in the Western Canada Sedimentary Basin (including the Interlake region) are remnants of extensive sheets of sediment that were deposited over the North American craton (Precambrian rock) and its western ocean margin (Norford et al. 1994). Carbonate rocks of the Paleozoic outcrop belt in southwestern Manitoba were subsequently eroded in the interval from the post-Devonian Period to the Mesozoic Era, when extensive karsting and channelling occurred (Bannatyne 1988). Present-day surficial bedrock exposures in the region decrease in geologic age from east to west, from Early Ordovician at Lake Winnipeg to Lower Devonian at Lake Manitoba (Figure 1). Marble Ridge lies in close proximity to the Ordovician-Silurian boundary and contains areas of exposed Silurian bedrock at the uppermost positions on the escarpment (personal observation).

\section{Species sampling}

A total of approximately 30 hours of sampling was conducted at Marble Ridge at various times over the 2008, 2010, and 2011 growing seasons. Sampling focused on saxicolous species (those growing on rock) and was restricted to habitats on the escarpment face and adjacent rock slabs, although one noteworthy species was collected in the adjoining alvar system. Species

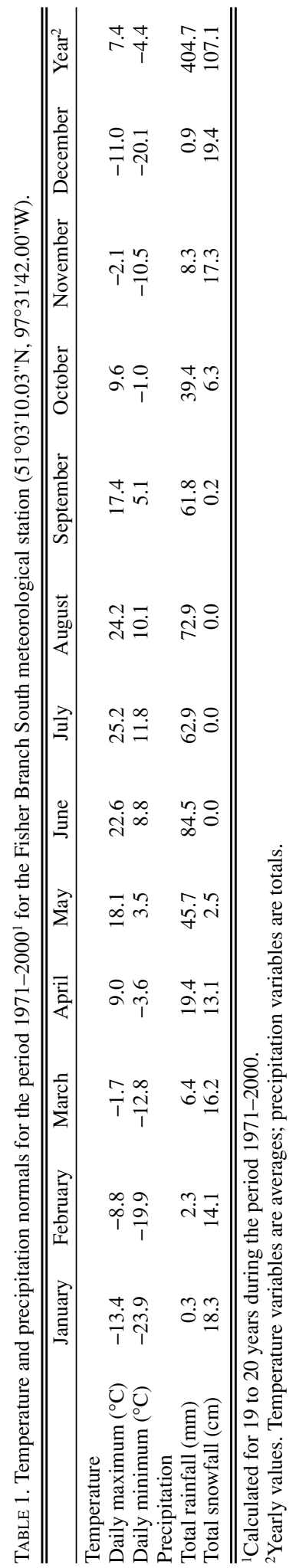


growing in forest habitats (e.g., tree trunks, dead wood, forest floor) are not reported here.

Taxonomic nomenclature for mosses follows Anderson et al. (1990), except Brachythecium laetum, which follows Robinson and Ignatov (1997) and Ignatov et al. (2008); Schistidium frigidum, which follows McIntosh (2007); and Syntrichia ruralis and S. norvegica, which follow Mishler (2007). Nomenclature for liverworts is based on Stotler and Crandall-Stotler (1977). For vascular plants, nomenclature is based on NatureServe (2011*). World phytogeographic distributions for mosses are based on Belland (1987) (unless otherwise noted) and for liverworts on Schuster (1966-1992), Damsholt (2002), and Belland (2011*). Vouchers of species have been deposited at the University of Manitoba herbarium (WIN) (herbarium acronym follows Thiers 2012*).

\section{Annotated List of Species}

A total of 58 species was documented at Marble Ridge: 51 mosses $(87.9 \%$ of the flora) and 7 liverworts $(12.1 \%)$. Two liverwort families (consisting of three species) and four moss species are reported for Manitoba for the first time (Canadian Endangered Species Conservation Council 2011*; NatureServe 2011*) the liverworts Athalamia hyalina (Sommert.) Hatt. (Cleveaceae), Mannia fragrans (Balbis) Frye et Clark (Aytoniaceae), and Mannia sibirica (K. Müll.) Frye et Clark (Aytoniaceae) and the mosses Brachythecium collinum (Schleich. ex C. Müll.) Schimp. in B.S.G., Grimmia teretinervis Limpr., Schistidium frigidum $\mathrm{H}$. H. Blom, and Seligeria donniana (Sm.) C. Müll. One species, Mannia fragrans, was not found on the escarpment itself but nearby on a thin layer of calcareous soil over dolomite bedrock in the adjacent alvar habitat.

The phytogeographic distribution of the bryophyte flora of the escarpment is predominantly circumboreal (58.6\% of the flora), with smaller proportions of other boreal, temperate, and arctic elements (Table 2). Documented species exhibited a wide variety of life forms (based on Hill et al. 2007), but dominant forms were rough mats $(29.3 \%)$, tufts $(20.7 \%)$, and turfs $(19.0 \%)$ (Table 3).

The following is an annotated list of all species growing on the escarpment and adjacent rocks. Species and families marked with $\uparrow$ are reported as new to the province of Manitoba, and those followed by the symbol $\nabla$ (ancient Greek element of water) are known to be associated with mesic microhabitats. All collection numbers are those of the author unless otherwise indicated. The abbreviation "c.fr." following collection numbers refers to specimens with sporophytes, whereas "c.ge." refers to specimens bearing asexual propagules. The same collection number was sometimes used for more than one species for expediency in the field. Collection numbers are associated with the following collection dates: 5261-5289, 24 April 2008; 5719-
TABLE 2. World phytogeographic distributions of bryophyte species documented at Marble Ridge.

\begin{tabular}{lcc}
\hline \hline Group & No. of species & \% of flora \\
\hline Cosmopolitan & 3 & 5.2 \\
Circumboreal & 34 & 58.6 \\
Boreal disjunct & 5 & 8.6 \\
Boreal endemic & 1 & 1.7 \\
Circumtemperate & 3 & 5.2 \\
Temperate disjunct & 4 & 6.9 \\
Temperate endemic & 1 & 1.7 \\
Circummontane & 0 & 0.0 \\
Montane disjunct & 0 & 0.0 \\
Montane endemic & 0 & 0.0 \\
Arctic-alpine & 6 & 10.3 \\
Distribution not known & 1 & 1.7 \\
Total & 58 & 100.0 \\
\hline \hline
\end{tabular}

TABLE 3. Life forms of bryophyte species documented at Marble Ridge.

\begin{tabular}{lcc}
\hline \hline Life form & \\
\hline Cushion & No. of species & \% of flora \\
Fan & 4 & 6.9 \\
Mat, rough & 1 & 1.7 \\
Mat, smooth & 17 & 29.3 \\
Mat, thalloid & 5 & 8.6 \\
Thread & 3 & 5.2 \\
Tuft & 1 & 1.7 \\
Turf & 12 & 20.7 \\
Weft & 11 & 19.0 \\
Total & 4 & 6.9 \\
\hline \hline
\end{tabular}

${ }^{1}$ Definitions of bryophyte life forms (adapted from Hill et al. 2007). Cushion: dome-shaped colony formed by variously oriented shoots with a central origin; fan: shoots arising from vertical bark or rock, branching repeatedly in horizontal plane; mat, rough: shoots that creep over substratum, having numerous erect lateral branches; mat, smooth: shoots that creep over substratum, having leafy branches that generally lie flat; mat, thalloid: shoots that creep over substratum, composed of a layer of thalli; thread: thread-like, variously oriented stems that crawl through or over substrate or vegetation; tuft: forming loose cushions not necessarily of central origin; turf: many loosely or closely packed vertical stems with limited branching.

5781, 16 July 2010; 6076-6114, 3 May 2011; 61156166, 22 May 2011; 6636-6661, 19 October 2011. Collection numbers that are not presented in the annotated list of species are either duplicate or unverified samples, or were collected at other locations in the Interlake.

\section{Liverworts}

AYTONIACEAE ${ }^{\dagger}$

Mannia fragrans (Balbis) Frye et Clark ${ }^{\dagger} \nabla$ MANITOBA: Rural Municipality of Fisher, Marble Ridge, between Fisher Branch and Hodgson, large thalloid mats of scattered gametophytes on thin calcareous mineral soil over limestone or dolomite bedrock in the adjacent alvar habitat, in association with Didymodon rigidulus 
var. rigidulus, Tortella fragilis, and Abietinella abietina, $51^{\circ} 11^{\prime} \mathrm{N}, 97^{\circ} 37^{\prime} \mathrm{W}$, Caners 6661.

Infrequent. Arctic-alpine (arctic; Damsholt 2002).

Mannia sibirica (K. Müll.) Frye et Clark $^{\dagger} \nabla$ MANITOBA: Rural Municipality of Fisher, Marble Ridge, between Fisher Branch and Hodgson, small thalloid mats on mineral soil over rock ledges, $51^{\circ} 11^{\prime} \mathrm{N}$, $97^{\circ} 37^{\prime} \mathrm{W}$, Caners 5744.

Plants had ventral scales with 1 appendage and several (810) oil bodies per cell, and lacked the brush of scales found at the ends of thalli in Mannia fragrans. Epidermal cells of the thallus had large trigones and air chambers that contained additional walls. The species is rare in North America, being reported in Canada from Ontario, where it is ranked by NatureServe as Critically Imperilled (S1), and in the United States from Iowa and Minnesota, where the species is unranked (NatureServe 2011*). Infrequent. Arctic-alpine (arctic; Damsholt 2002).

\section{CleveaceaE ${ }^{\dagger}$}

Athalamia hyalina (Sommert.) Hatt. ${ }^{\dagger} \nabla$ MANITOBA: Rural Municipality of Fisher, Marble Ridge, between Fisher Branch and Hodgson, small to large grey-green thalloid mats on mineral soil over rock ledges in shaded, humid areas, $51^{\circ} 11^{\prime} \mathrm{N}, 97^{\circ} 37^{\prime} \mathrm{W}$, Caners 5780 c.fr., 5781 c.fr., 6107 c.fr.

The species is best distinguished by gynoecia that form away from thallus margins. Infrequent on Marble Ridge. Arctic-alpine (subarctic-subalpine; Damsholt 2002).

\section{GEOCALYCACEAE}

Lophocolea minor Nees $\nabla$ MANITOBA: Rural Municipality of Fisher, Marble Ridge, between Fisher Branch and Hodgson, small smooth mats on rock slabs close to the forest floor or as scattered shoots among other bryophytes, $51^{\circ} 11^{\prime} \mathrm{N}, 97^{\circ} 37^{\prime} \mathrm{W}$, Caners 5745 c.ge.

Infrequent. Circumboreal (Belland 2011*).

JUBULACEAE

Frullania inflata Gott. $\nabla$ MANITOBA: Rural Municipality of Fisher, Marble Ridge, between Fisher Branch and Hodgson, thin, smooth dark green mats on vertical surfaces or the undersides of shaded, humid crevices, $51^{\circ} 11^{\prime} \mathrm{N}, 97^{\circ} 37^{\prime} \mathrm{W}$, Caners 5742 c.fr., 5770 .

Specimens had clavate papillae of the perianth mouth, conforming with descriptions of $F$. saxicola (sometimes considered synonymous with $F$. inflata). In Manitoba, $F$. inflata has previously been reported from the Winnipeg area (Stringer and Stringer 1974a; Stringer and Stringer 1974b). Moderately frequent. Circumtemperate (widespread in temperate and warm areas of North America south to Mexico; Schuster 1966-1992).

\section{Plagiochilaceae}

Plagiochila porreloides (Torrey ex Nees) Lindenb. $\nabla$ MANITOBA: Rural Municipality of Fisher, Marble Ridge, between Fisher Branch and Hodgson, small wefts or as single shoots among other bryophytes, over rock ledges and in microhabitats that receive greater moisture, $51^{\circ} 11^{\prime} \mathrm{N}, 97^{\circ} 37^{\prime} \mathrm{W}$, Caners 5721.

Infrequent. Circumboreal (Belland 2011*).

\section{RADULACEAE}

Radula complanata (L.) Dum. $\nabla$ MANITOBA: Rural Municipality of Fisher, Marble Ridge, between Fisher Branch and Hodgson, small smooth mats on surfaces of rock slabs adjacent to the escarpment, often near ground level, $51^{\circ} 11^{\prime} \mathrm{N}, 97^{\circ} 37^{\prime} \mathrm{W}$, Caners 5723 c.fr., 6113 c.fr.

Infrequent. Circumboreal (Belland 2011*).

\section{Mosses}

\section{AMBLYSTEGIACEAE}

Campylium chrysophyllum (Brid.) J. Lange $\nabla$ MANITOBA: Rural Municipality of Fisher, Marble Ridge, between Fisher Branch and Hodgson, small rough mats on humus over rock ledges or as single shoots among other bryophytes, $51^{\circ} 11^{\prime} \mathrm{N}, 97^{\circ} 37^{\prime} \mathrm{W}$, Caners 5732 , 5734.

Moderately frequent. Circumboreal.

Campylium hispidulum (Brid.) Mitt. $\nabla$ MANITOBA: Rural Municipality of Fisher, Marble Ridge, between Fisher Branch and Hodgson, small rough mats on humus over ledges or more commonly as single shoots among other bryophytes, $51^{\circ} 11^{\prime} \mathrm{N}, 97^{\circ} 37^{\prime} \mathrm{W}$, Caners 6106.

$$
\text { Infrequent. Boreal endemic. }
$$

Conardia compacta (C. Müll.) Robins. $\nabla$ MANITOBA: Rural Municipality of Fisher, Marble Ridge, between Fisher Branch and Hodgson, small rough mats along ledges or crevices, $51^{\circ} 11^{\prime} \mathrm{N}, 97^{\circ} 37^{\prime} \mathrm{W}$, Caners 5289 c.ge., 5731 c.ge., 5771 c.ge.

Infrequent. Distribution not known (in North America the species has a temperate distribution; Crum and Hedenäs 2010*).

\section{ANOMODONTACEAE}

Anomodon minor (Hedw.) Fürnr.-MANITOBA: Rural Municipality of Fisher, Marble Ridge, between Fisher Branch and Hodgson, small rough mats along escarpment ledges, often in association with Anomodon rostratus, $51^{\circ} 11^{\prime} \mathrm{N}, 97^{\circ} 37^{\prime} \mathrm{W}$, Caners 5262 , 5264, 5734.

Infrequent. Temperate disjunct.

Anomodon rostratus (Hedw.) Schimp.-MANITOBA: Rural Municipality of Fisher, Marble Ridge, between Fisher Branch and Hodgson, large rough mats along escarpment ledges, $51^{\circ} 11^{\prime} \mathrm{N}, 97^{\circ} 37^{\prime} \mathrm{W}$, Caners 5269 , 5272, 5733, 5755 .

The species has been reported only once from Manitoba, also from the Interlake region, at Buffalo Lake north of Grand Rapids (CANM 280285 and 280299). Frequent. Temperate disjunct.

\section{AUlaComNiaceAe}

Aulacomnium palustre (Hedw.) Schwaegr. $\nabla$ MANITOBA: Rural Municipality of Fisher, Marble Ridge, between Fisher Branch and Hodgson, small turf on soil 
over an adjacent rock slab, near the ground surface, $51^{\circ} 11^{\prime} \mathrm{N}, 97^{\circ} 37^{\prime} \mathrm{W}$, Caners 6157.

Only a single colony was observed. Infrequent. Circumboreal.

\section{BRACHYTHECIACEAE}

Brachythecium acuminatum (Hedw.) Aust.-MANITOBA: Rural Municipality of Fisher, Marble Ridge, between Fisher Branch and Hodgson, large rough mats over escarpment ledges and adjacent rock slabs, $51^{\circ} 11^{\prime} \mathrm{N}, 97^{\circ} 37^{\prime} \mathrm{W}$, Caners $5273,5286$.

Frequent. Temperate endemic.

Brachythecium collinum (Schleich. ex C. Müll.) Schimp. in B.S.G. ${ }^{\dagger}-$ MANITOBA: Rural Municipality of Fisher, Marble Ridge, between Fisher Branch and Hodgson, small rough mats over escarpment ledges, infrequent on rock slabs, $51^{\circ} 11^{\prime} \mathrm{N}, 97^{\circ} 37^{\prime} \mathrm{W}$, Caners 6089, 6091.

Infrequent. Boreal disjunct.

Brachythecium laetum (Brid.) B.S.G.-MANITOBA: Rural Municipality of Fisher, Marble Ridge, between Fisher Branch and Hodgson, small rough mats over escarpment ledges; infrequent on rock slabs, $51^{\circ} 11^{\prime} \mathrm{N}$, 97³7'W, Caners 5750, 6076.

Infrequent. Temperate disjunct.

Brachythecium salebrosum (Web. \& Mohr) Schimp. in B.S.G.-MANITOBA: Rural Municipality of Fisher, Marble Ridge, between Fisher Branch and Hodgson, small to large rough mats on rock slabs adjacent to the escarpment, $51^{\circ} 11^{\prime} \mathrm{N}, 97^{\circ} 37^{\prime} \mathrm{W}$, Caners 6106.

Moderately frequent. Circumboreal.

Eurhynchium pulchellum (Hedw.) Jenn.-MANITOBA: Rural Municipality of Fisher, Marble Ridge, between Fisher Branch and Hodgson, small rough mats on rock slabs adjacent to the escarpment, $51^{\circ} 11^{\prime} \mathrm{N}$, $97^{\circ} 37^{\prime} \mathrm{W}$, Caners 5723.

Infrequent on the escarpment but frequent in adjacent forested areas. Circumboreal.

\section{BRYACEAE}

Bryum caespiticium Hedw.-MANITOBA: Rural Municipality of Fisher, Marble Ridge, between Fisher Branch and Hodgson, small turfs on humus over rock ledges or as single shoots among other bryophytes, $51^{\circ} 11^{\prime} \mathrm{N}, 97^{\circ} 37^{\prime} \mathrm{W}$, Caners 5764 c.fr.

Moderately frequent. Cosmopolitan.

Bryum pseudotriquetrum (Hedw.) Gaertn. et al. $\nabla$ MANITOBA: Rural Municipality of Fisher, Marble Ridge, between Fisher Branch and Hodgson, small turfs on humus over rock ledges or as single shoots among other bryophytes, Caners 5721 .

Moderately frequent. Circumboreal.

Pohlia cruda (Hedw.) Lindb.-MANITOBA: Rural Municipality of Fisher, Marble Ridge, between Fisher
Branch and Hodgson, small tufts on soil over rock ledges, $51^{\circ} 11^{\prime} \mathrm{N}, 97^{\circ} 37^{\prime} \mathrm{W}$, Caners 6645 .

Infrequent. Circumboreal.

Rhodobryum ontariense (Kindb.) Par. in Kindb. $\nabla$ MANITOBA: Rural Municipality of Fisher, Marble Ridge, between Fisher Branch and Hodgson, large tufts on deep humus over ledges and adjacent rock slabs, $51^{\circ} 11^{\prime} \mathrm{N}, 97^{\circ} 37^{\prime} \mathrm{W}$, Caners $5275,5720,6079$ c.fr.

Frequent. Circumtemperate.

\section{DitRICHACEAE}

Distichium capillaceum (Hedw.) Bruch \& Schimp. in B.S.G. $\nabla$ MANITOBA: Rural Municipality of Fisher, Marble Ridge, between Fisher Branch and Hodgson, small tufts on soil over rock ledges, $51^{\circ} 11^{\prime} \mathrm{N}, 97^{\circ} 37^{\prime} \mathrm{W}$, Caners 5276 c.fr., $5740,5753$.

Moderately frequent. Circumboreal.

Ditrichum flexicaule (Schwaegr.) Hampe-MANITOBA: Rural Municipality of Fisher, Marble Ridge, between Fisher Branch and Hodgson, small tufts on rock slabs adjacent to the escarpment, $51^{\circ} 11^{\prime} \mathrm{N}$, $97^{\circ} 37^{\prime} \mathrm{W}$, Caners 6160.

Infrequent. Circumboreal.

\section{ENCALYPTACEAE}

Encalypta procera Bruch-MANITOBA: Rural Municipality of Fisher, Marble Ridge, between Fisher Branch and Hodgson, small tufts on soil over rock ledges, $51^{\circ} 11^{\prime} \mathrm{N}, 97^{\circ} 37^{\prime} \mathrm{W}$, Caners 5265 c.fr., 5267 c.ge., 5272 c.ge., 5285,5753 .

Moderately frequent. Circumboreal.

Encalypta rhaptocarpa Schwaegr-MANITOBA: Rural Municipality of Fisher, Marble Ridge, between Fisher Branch and Hodgson, small tufts on soil over rock ledges, $51^{\circ} 11^{\prime} \mathrm{N}, 97^{\circ} 37^{\prime} \mathrm{W}$, Caners 5737 c.fr.

Infrequent. Circumboreal.

\section{FISSIDENTACEAE}

Fissidens bryoides Hedw. $\nabla$ MANITOBA: Rural Municipality of Fisher, Marble Ridge, between Fisher Branch and Hodgson, small turfs on soil over rock ledges, $51^{\circ} 11^{\prime} \mathrm{N}, 97^{\circ} 37^{\prime} \mathrm{W}$, Caners 5735, 5777.

Infrequent. Circumtemperate.

\section{GRIMMIACEAE}

Grimmia teretinervis Limpr. $^{\dagger} \nabla$ MANITOBA: Rural Municipality of Fisher, Marble Ridge, between Fisher Branch and Hodgson, numerous large cushions on rock surfaces along the length of the escarpment, on rock slabs alongside the escarpment, and on boulders in the adjacent alvar system, $51^{\circ} 11^{\prime} \mathrm{N}, 97^{\circ} 37^{\prime} \mathrm{W}$, Caners $5728,5729,6652,6653,6660$.

The species is abundant at the site and appears to preferentially colonize large blocks of smooth, thick-bedded dolomite, as high colony densities were frequently observed on these surfaces. Many colonies appeared to be growing from horizontal fissures in the rock surface (Figure 2). This occurrence in Manitoba represents one of relatively few localities 
of the species in central North America (Hastings 2002) and is potentially one of the largest populations of the species on the continent ( $R$. Hastings, personal communication, 19 October 2011), supporting more than 1000 individual colonies by preliminary estimates. The next closest record of the species is approximately $650 \mathrm{~km}$ to the southeast in the Thunder Bay District of Ontario (La Verendrye Provincial Park; CANM 299965). Further research is being conducted on the species at Marble Ridge. Frequent. Temperate disjunct.

Schistidium frigidum H. H. Blom ${ }^{\dagger}-$ MANITOBA: Rural Municipality of Fisher, Marble Ridge, between Fisher Branch and Hodgson, small cushion on vertical rock surface, $51^{\circ} 11^{\prime} \mathrm{N}, 97^{\circ} 37^{\prime} \mathrm{W}$, Caners 5741 c.fr.

Only a single colony was observed. Infrequent. Arcticalpine (arctic-montane; Hill et al. 2007).

\section{HeDWIGIACEAE}

Hedwigia ciliata (Hedw.) P. Beauv.-MANITOBA: Rural Municipality of Fisher, Marble Ridge, between Fisher Branch and Hodgson, small to large rough mats on rock slabs adjacent to the escarpment, $51^{\circ} 11^{\prime} \mathrm{N}$, 97³7'W, Caners 5719, 5725 c.fr.

Moderately frequent. Cosmopolitan.

\section{HYLOCOMIACEAE}

Hylocomium splendens (Hedw.) Schimp. in B.S.G.MANITOBA: Rural Municipality of Fisher, Marble Ridge, between Fisher Branch and Hodgson, large weft over an escarpment ledge, $51^{\circ} 11^{\prime} \mathrm{N}, 97^{\circ} 37^{\prime} \mathrm{W}$, Caners sight record.

Only a single colony was observed on the escarpment, but the species was common in the adjacent conifer-dominated forest. Infrequent. Circumboreal.

\section{HYPNACEAE}

Hypnum vaucheri Lesq.-MANITOBA: Rural Municipality of Fisher, Marble Ridge, between Fisher Branch and Hodgson, large rough mats over escarpment ledges and adjacent rock slabs, $51^{\circ} 11^{\prime} \mathrm{N}, 97^{\circ} 37^{\prime} \mathrm{W}$, Caners $5270,5284,5752,6082$ c.fr.

The species is widely distributed in boreal and arctic areas, and is predominantly continental in distribution in North America (Schofield 2006*). A few specimens at Marble Ridge had blunt foliose pseudoparaphyllia. Frequent. Arctic-alpine.

Isopterygiopsis pulchella (Hedw.) Iwats.-MANITOBA: Rural Municipality of Fisher, Marble Ridge, between Fisher Branch and Hodgson, small rough mats on soil over rock ledges, $51^{\circ} 11^{\prime} \mathrm{N}, 97^{\circ} 37^{\prime} \mathrm{W}$, Caners 5763.

Moderately frequent. Circumboreal.

Platydictya jungermannioides (Brid.) Crum $\nabla$ MANITOBA: Rural Municipality of Fisher, Marble Ridge, between Fisher Branch and Hodgson, small colonies as threads on soil over rock ledges, $51^{\circ} 11^{\prime} \mathrm{N}, 97^{\circ} 37^{\prime} \mathrm{W}$, Caners 5268, 5735.

Frequent. Circumboreal.

Pylaisiella polyantha (Hedw.) Grout-MANITOBA: Rural Municipality of Fisher, Marble Ridge, between
Fisher Branch and Hodgson, small rough mats on vertical rock faces, $51^{\circ} 11^{\prime} \mathrm{N}, 97^{\circ} 37^{\prime} \mathrm{W}$, Caners 6637 c.fr., 6642 c.fr.

Infrequent on rock surfaces on the escarpment but frequent on bark at the base of Trembling Aspen in the immediate vicinity. Circumboreal.

\section{LESKEACEAE}

Leskeella nervosa (Brid.) Loeske-MANITOBA: Rural Municipality of Fisher, Marble Ridge, between Fisher Branch and Hodgson, small rough mats on rock faces, on both the escarpment and less frequently on adjacent rock slabs, $51^{\circ} 11^{\prime} \mathrm{N}, 97^{\circ} 37^{\prime} \mathrm{W}$, Caners 5727 c.ge.

Infrequent. Circumboreal.

Pseudoleskeella tectorum (Funck ex Brid.) Kindb. in Broth.-MANITOBA: Rural Municipality of Fisher, Marble Ridge, between Fisher Branch and Hodgson, small rough mats on humus over rock ledges, $51^{\circ} 11^{\prime} \mathrm{N}$, 97²3'W, Caners 5281, 5282, 5726, 5738, 5754, 5770.

Moderately frequent. Boreal disjunct.

\section{MnIACEAE}

Mnium ambiguum H. Müll.-MANITOBA: Rural Municipality of Fisher, Marble Ridge, between Fisher Branch and Hodgson, small turfs on humus over escarpment ledges, $51^{\circ} 11^{\prime} \mathrm{N}, 97^{\circ} 37^{\prime} \mathrm{W}$, Caners 5277 , 5721 c.fr.

Moderately frequent. Circumboreal.

Mnium spinulosum Bruch \& Schimp. in B.S.G.MANITOBA: Rural Municipality of Fisher, Marble Ridge, between Fisher Branch and Hodgson, small turfs on humus over escarpment ledges and also on adjacent rock slabs, $51^{\circ} 11^{\prime} \mathrm{N}, 97^{\circ} 37^{\prime} \mathrm{W}$, Caners 5771 .

Moderately frequent. Boreal disjunct.

Mnium thomsonii Schimp.-MANITOBA: Rural Municipality of Fisher, Marble Ridge, between Fisher Branch and Hodgson, small turfs on humus over escarpment ledges, $51^{\circ} 11^{\prime} \mathrm{N}, 97^{\circ} 37^{\prime} \mathrm{W}$, Caners 5745 .

Infrequent. Circumboreal.

Plagiomnium cuspidatum (Hedw.) T. Kop.-MANITOBA: Rural Municipality of Fisher, Marble Ridge, between Fisher Branch and Hodgson, small smooth mats on adjacent rock slabs, often occurring close to the forest floor, $51^{\circ} 11^{\prime} \mathrm{N}, 97^{\circ} 37^{\prime} \mathrm{W}$, Caners 6083 c.fr., 6108 c.fr.

Moderately frequent. Circumboreal.

Plagiomnium medium (Bruch \& Schimp. in B.S.G.) T. Kop. $\nabla$ MANITOBA: Rural Municipality of Fisher, Marble Ridge, between Fisher Branch and Hodgson, small smooth mats on adjacent rock slabs, often occurring close to the forest floor, $51^{\circ} 11^{\prime} \mathrm{N}, 97^{\circ} 37^{\prime} \mathrm{W}$, Caners 6657.

Moderately frequent. Circumboreal. 


\section{NECKERACEAE}

Neckera pennata Hedw.-MANITOBA: Rural Municipality of Fisher, Marble Ridge, between Fisher Branch and Hodgson, small fan on humus over vertical rock surface, $51^{\circ} 11^{\prime} \mathrm{N}, 97^{\circ} 37^{\prime} \mathrm{W}$, Caners 6643 .

Only a single colony was observed. Infrequent. Boreal disjunct.

\section{ORTHOTRICHACEAE}

Orthotrichum anomalum Hedw.-MANITOBA: Rural Municipality of Fisher, Marble Ridge, between Fisher Branch and Hodgson, small cushions on vertical rock surfaces along the escarpment and on adjacent rock slabs, $51^{\circ} 11^{\prime} \mathrm{N}, 97^{\circ} 37^{\prime} \mathrm{W}$, Caners 5265 c.fr., 5282 c.fr., 5722 c.fr., 5763 c.fr., 5765 c.fr.

Frequent. Circumboreal.

Orthotrichum obtusifolium Brid.-MANITOBA: Rural Municipality of Fisher, Marble Ridge, between Fisher Branch and Hodgson, small cushion on vertical rock surface on the escarpment, $51^{\circ} 11^{\prime} \mathrm{N}, 97^{\circ} 37^{\prime} \mathrm{W}$, Caners 6658 c.ge.

Only a single colony was observed. This obligate corticolous species is rarely found on rock in North America, but is reported as growing on calcareous rock in subarctic and subalpine regions of Fennoscandia (Crum and Anderson 1981). Nyholm (1974) indicates the species occurs rarely on rocks. Infrequent. Circumboreal.

\section{PotTiaceae}

Barbula convoluta Hedw.-MANITOBA: Rural Municipality of Fisher, Marble Ridge, between Fisher Branch and Hodgson, small turfs on soil over escarpment ledges, $51^{\circ} 11^{\prime} \mathrm{N}, 97^{\circ} 37^{\prime} \mathrm{W}$, Caners 5779.

Infrequent. Circumboreal.

Bryoerythrophyllum recurvirostre (Hedw.) ChenMANITOBA: Rural Municipality of Fisher, Marble Ridge, between Fisher Branch and Hodgson, small turfs on soil over rock ledges, $51^{\circ} 11^{\prime} \mathrm{N}, 97^{\circ} 37^{\prime} \mathrm{W}$, Caners 5265 c.fr., 5269 c.fr., 5285 c.fr., 5724,5769 c.fr.

Frequent. Cosmopolitan.

Didymodon rigidulus Hedw. var. rigidulus $\nabla$ MANITOBA: Rural Municipality of Fisher, Marble Ridge, between Fisher Branch and Hodgson, small tufts on soil over rock ledges, $51^{\circ} 11^{\prime} \mathrm{N}, 97^{\circ} 37^{\prime} \mathrm{W}$, Caners 5732 , 5763, 5772, 5776 .

Moderately frequent. Circumboreal.

Gymnostomum aeruginosum Sm. $\nabla$ MANITOBA: Rural Municipality of Fisher, Marble Ridge, between Fisher Branch and Hodgson, small turfs on soil over rock ledges, or on the undersides of crevices above rock ledges, $51^{\circ} 11^{\prime} \mathrm{N}, 97^{\circ} 37^{\prime} \mathrm{W}$, Caners 5269,5279 , 5756, 5758, 5767.

Frequent. Circumboreal.

Syntrichia norvegica F. Weber-MANITOBA: Rural Municipality of Fisher, Marble Ridge, between Fisher Branch and Hodgson, small tuft on humus over adjacent rock slab, $51^{\circ} 11^{\prime} \mathrm{N}, 97^{\circ} 37^{\prime} \mathrm{W}$, Caners 6159.
Only a single colony was observed. Infrequent. Arcticalpine.

Syntrichia ruralis (Hedwig) F. Weber \& D. MohrMANITOBA: Rural Municipality of Fisher, Marble Ridge, between Fisher Branch and Hodgson, small tufts on humus over adjacent rock slabs, $51^{\circ} 11^{\prime} \mathrm{N}$, $97^{\circ} 37^{\prime} \mathrm{W}$, Caners 5723, 5762.

Frequent. Circumboreal.

Tortella fragilis (Hook. \& Wils in Drumm.) Limpr.MANITOBA: Rural Municipality of Fisher, Marble Ridge, between Fisher Branch and Hodgson, small tufts on soil over rock ledges, $51^{\circ} 11^{\prime} \mathrm{N}, 97^{\circ} 37^{\prime} \mathrm{W}$, Caners 5269, 5274, 5282 .

Frequent. Circumboreal.

Tortella tortuosa (Hedw.) Limpr-—MANITOBA: Rural Municipality of Fisher, Marble Ridge, between Fisher Branch and Hodgson, small tufts on soil over rock ledges, $51^{\circ} 11^{\prime} \mathrm{N}, 97^{\circ} 37^{\prime} \mathrm{W}$, Caners 5274, 5763.

Infrequent. Circumboreal.

Tortula mucronifolia Schwaegr--MANITOBA: Rural Municipality of Fisher, Marble Ridge, between Fisher Branch and Hodgson, small tufts on soil over rock ledges, $51^{\circ} 11^{\prime} \mathrm{N}, 97^{\circ} 37^{\prime} \mathrm{W}$, Caners 5265 c.fr.

Moderately frequent. Circumboreal.

PTERIGYNANDRACEAE

Myurella julacea (Schwaegr.) Schimp. in B.S.G. $\nabla$ MANITOBA: Rural Municipality of Fisher, Marble Ridge, between Fisher Branch and Hodgson, small rough mats on soil and humus over rock ledges, $51^{\circ} 11^{\prime} \mathrm{N}, 97^{\circ} 37^{\prime} \mathrm{W}$, Caners 5269, 5287, 5736, 5747.

Some plants with leaves widely spaced and terminating in a short, often recurved apiculus, approaching Myurella tenerrima in appearance. Frequent. Circumboreal.

\section{SeligeriacEAe}

Seligeria donniana (Sm.) C. Müll. ${ }^{\dagger} \nabla$ MANITOBA: Rural Municipality of Fisher, Marble Ridge, between Fisher Branch and Hodgson, large turf on vertical rock walls in a shaded, humid crevice, $51^{\circ} 11^{\prime} \mathrm{N}, 97^{\circ} 37^{\prime} \mathrm{W}$, Caners 5288 c.fr. junct.

Only a single colony was observed. Infrequent. Boreal dis-

\section{THUIDIACEAE}

Abietinella abietina (Hedw.) Fleisch.-MANITOBA: Rural Municipality of Fisher, Marble Ridge, between Fisher Branch and Hodgson, large wefts over escarpment ledges and adjacent rock slabs, $51^{\circ} 11^{\prime} \mathrm{N}, 97^{\circ} 37^{\prime} \mathrm{W}$, Caners 5263, 5266.

Frequent. Circumboreal.

Thuidium recognitum (Hedw.) Lindb. $\nabla$ MANITOBA: Rural Municipality of Fisher, Marble Ridge, between Fisher Branch and Hodgson, small to large wefts on humus over ledges and adjacent rock slabs, $51^{\circ} 11^{\prime} \mathrm{N}$, $97^{\circ} 37^{\prime} \mathrm{W}$, Caners 5779.

Moderately frequent. Circumboreal. 


\section{Discussion}

Marble Ridge supports a variety of bryophytes with differing floristic affinities and life forms, including several species that are reported for Manitoba for the first time. The fact that the escarpment can support this diverse assemblage of species is largely attributable to the concurrence of several habitat features. Namely, the escarpment contains an assortment of surfaces, ledges, and crevices, with varying degrees of humidity and exposure, that create a diversity of microhabitats for bryophyte species with different biological requirements. The species Athalamia hyalina, Frullania inflata, and Seligeria donniana, for example, were found almost exclusively in rock crevices or sheltered microhabitats with high humidity and low exposure. In comparison, vertical rock faces and adjacent rock slabs were more exposed to air currents and incident solar radiation, and they supported a higher number of bryophytes that were apparently tolerant of drier growing conditions, including Abietinella abietina, Anomodon rostratus, Brachythecium acuminatum, Hedwigia ciliata, Orthotrichum anomalum, and Syntrichia ruralis.

The wide range of bryophyte life forms documented along the escarpment may be indicative of the diversity of microhabitats at the site. Bryophyte life forms correlate strongly with moisture and light conditions, and can provide insights into the local environment (Gimingham and Birse 1957; Bates 1998). On hard substrates, including rock, rough mats are commonly associated with dry and shaded habitats, whereas tall turfs are more closely affiliated with mesic and more exposed habitats (Bates 1998). In comparison, short turfs and many tufts (sensu Hill et al. 2007) are often found in microhabitats that are both dry and exposed. Dominance of these life forms at Marble Ridge confirms the general observation that a range of microhabitat conditions are present at the site.

Two other important features of the escarpment for maintaining bryophytes are the east-facing aspect and the forest canopy cover which in many places help maintain shaded, cooler, and more humid microhabitats for species by reducing incident solar radiation, surface and air temperatures, and wind. Approximately one-third of all species documented at Marble Ridge are mesophytes; they would be detrimentally affected by drier conditions along the escarpment with forest canopy removal or a more arid regional climate. Any human-induced disturbances to forest or bedrock habitat in the immediate vicinity of Marble Ridge should consider the potential impacts on species and their specialized habitat requirements.

Several species documented on Marble Ridge are likely to be found on other bedrock outcrops of varying size in the Interlake Plain Ecoregion, especially species with wide phytogeographic distributions like the circumboreal ones. However, some species will almost certainly remain regionally uncommon in view of the exceptional growing conditions at Marble Ridge and the comparatively few known occurrences of these species in other parts of Canada (e.g., Athalamia hyalina, Frullania inflata, Grimmia teretinervis, Mannia sibirica, Seligeria donniana). Anomodon rostratus is known from several localities in most eastern provinces (Canadian Endangered Species Conservation Council 2011*) but is likely uncommon in Manitoba and Saskatchewan, where the species approaches its western distributional limits in the country. Inventories of bryophytes at other bedrock exposures along the Paleozoic outcrop belt in southwestern Manitoba are required 1) to better understand the occurrences of uncommon species in the region and the habitat conditions under which they are most likely to occur and 2) to assess the conservation value of bedrock exposures for their capacity to support saxicolous bryophytes.

The large proportion of circumboreal species at Marble Ridge is not surprising, given that the site is located in the Boreal Plains Ecozone. However, the majority of species (five out of seven) reported here as new to the province have phytogeographic distributions other than circumboreal (e.g., arctic, temperate). This suggests that Marble Ridge plays an important role in supporting both a large number of species characteristic of the boreal biome and those with outlying floristic affinities. Conservation and management plans in Interlake Manitoba should consider the inherent value of Marble Ridge, and potentially other geologic formations in maintaining regional biodiversity.

\section{Acknowledgements}

I thank Kell Damsholt (Botanical Museum, University of Copenhagen) for assistance in identifying several liverworts. Roxanne Hastings (Royal Alberta Museum, Edmonton) identified the collections of Grimmia teretinervis, provided insightful discussions about the species, and commented on an earlier version of the manuscript. Michael Ignatov (Main Botanical Garden, Russian Academy of Sciences) verified a few collections of Brachythecium. Terry McIntosh (Biospherics Environmental, Vancouver) identified the collection of Schistidium frigidum. Comments from two anonymous reviewers and Associate Editor Charles D. Bird improved the manuscript.

\section{Documents Cited (marked $*$ in text)}

Belland, R. J. 2011. World distributions of Canadian liverworts. Unpublished database.

Canadian Endangered Species Conservation Council. 2011. Wild Species 2010: The general status of species in Canada. National General Status Working Group, Ottawa.

Crum, H. A., and L. Hedenäs. 2010. Conardia. Flora of North America North of Mexico, Provisional Publication. 
Flora of North America Association. http://www.mobot.org /plantscience/bfna/V2/AmblConardia.htm. (Accessed 24 September 2011).

Environment Canada. 2011. Canadian climate normals: 1971-2000. Fisher Branch South. http://climate.weather office.gc.ca/climate_normals/index_e.html. (Accessed 24 September 2011).

Government of Manitoba. 2011. Mineral disposition maps. Mineral Resources Division, Winnipeg. http://www.mani toba.ca/iem/mrd/geo/gis/minesmaps.html. (Accessed 24 September 2011).

NatureServe. 2011. NatureServe Explorer: An online encyclopedia of life [online]. Version 7.1. NatureServe, Arlington, Virginia. http://www.natureserve.org/explorer. (Accessed 24 September 2011).

Reschke, C., R. Reid, J. Jones, T. Feeney, and H. Potter. 1999. Conserving Great Lakes alvars: Final Technical Report of the International Alvar Conservation Initiative. The Nature Conservancy, Great Lakes Program, Chicago.

Schofield, W. B. 2006. Hypnum. Flora of North America North of Mexico, Provisional Publication. Flora of North America Association. http://www.mobot.org/plantscience /BFNA/V2/HypnHypnum.htm. (Accessed 24 September 2011).

Thiers, B. 2012. Index Herbariorum: A global directory of public herbaria and associated staff. New York Botanical Garden's Virtual Herbarium. http://sciweb.nybg.org/sci ence2/IndexHerbariorum.asp. (Accessed 10 April 2012).

\section{Literature Cited}

Anderson, L. E., H. A. Crum, and G. R. Buck. 1990. List of the mosses of North America north of Mexico. The Bryologist 93: 448-499.

Bannatyne, B. B. 1988. Dolomite resources of southern Manitoba. Economic Geology Report ER85-1. Manitoba Energy and Mines, Geological Services, Winnipeg.

Bates, J. W. 1998. Is 'life-form' a useful concept in bryophyte ecology? Oikos 82: 223-237.

Belland, R. J. 1987. The moss flora of the Gulf of St. Lawrence region: Ecology and phytogeography. Journal of the Hattori Botanical Laboratory 62: 205-267.

Crum, H. A., and L. E. Anderson. 1981. Mosses of eastern North America. 2 vols. Columbia University Press, New York.

Damsholt, K. 2002. Illustrated flora of Nordic liverworts and hornworts. Nordic Bryological Society, Lund.

Ecological Stratification Working Group. 1995. A national ecological framework for Canada. Agriculture and AgriFood Canada, Research Branch, Centre for Land and Biological Resources Research and Environment Canada, State of the Environment Directorate, Ecozone Analysis Branch, Ottawa/Hull. Report and national map at 1:7 500000 scale.

Foote, K. G. 1966. The vegetation of lichens and bryophytes on limestone outcrops in the driftless area of Wisconsin. The Bryologist 69: 265-292.

Gimingham, C. H., and E. M. Birse. 1957. Ecological studies on growth-form in bryophytes: I. Correlations between growth-form and habitat. Journal of Ecology 45: 533-545.

Glass, D. J. Editor. 1990. Lexicon of Canadian Stratigraphy. Volume 4. Western Canada, including eastern British Columbia, Alberta, Saskatchewan, and southern Manitoba. Canadian Society of Petroleum Geologists, Calgary.

Groom, H. D. 1985. Surficial geology and aggregate resources of the Fisher Branch area: Local Government Dis- trict of Fisher and Rural Municipality of Bifrost. Aggregate Report AR84-2. Manitoba Energy and Mines, Mines Branch, Winnipeg.

Haig, A. R., U. Matthes, and D. W. Larson. 2000. Effects of natural habitat fragmentation on the species richness, diversity, and composition of cliff vegetation. Canadian Journal of Botany 78: 786-797.

Hastings, R. I. 2002. Biogeography of Grimmia teretinervis (Bryopsida, Grimmiaceae) in North America. The Bryologist 105: 262-266.

Hill, M. O., C. D. Preston, S. D. S. Bosanquet, and D. B. Roy. 2007. BRYOATT: Attributes of British and Irish mosses, liverworts and hornworts. Centre for Ecology and Hydrology, Cambridge.

Ignatov, M. S., I. A. Milyutina, and V. K. Bobrova. 2008. Problematic groups of Brachythecium and Eurhynchiastrum (Brachytheciaceae, Bryophyta) and taxonomic solutions suggested by nrITS sequences. Arctoa 17: 113-138.

Land Resource Unit. 1999. Soils and terrain. Rural Municipality of Fisher. Information Bulletin 99-18. Brandon Research Centre, Research Branch, Agriculture and AgriFood Canada, Brandon.

McIntosh, T. T. 2007. Schistidium. Pages 207-225 in Bryophyta: Mosses, Part 1. Vol. 27 of the Flora of North America North of Mexico. Edited by the Flora of North America Editorial Committee. Oxford University Press, New York.

Mishler, B. D. 2007. Syntrichia. Pages 618-627 in Bryophyta: Mosses, Part 1. Vol. 27 of the Flora of North America North of Mexico. Edited by the Flora of North America Editorial Committee. Oxford University Press, New York.

Norford, B. S., F. M. Haidl, R. K. Bezys, M. P. Cecile, H. R. McCabe, and D. F. Paterson. 1994. Middle Ordovician to lower Devonian strata of the western Canada sedimentary basin. In Geological Atlas of the Western Canada Sedimentary Basin. Edited by G. D. Mossop and I. Shetsen. Canadian Society of Petroleum Geologists and Alberta Research Council. Special Report 4. Online at Alberta Geological Survey. http://www.ags.gov.ab.ca/pub lications/wcsb_atlas/atlas.html. (Accessed 24 September 2011).

Nyholm, E. 1974. Illustrated moss flora of Fennoscandia. II, Musci. Fasc. 4. Swedish Natural Science Research Council, Stockholm.

Robinson, H., and M. S. Ignatov. 1997. Brachythecium laetum (Brid.) B.S.G. the correct name for the species commonly known as Brachythecium oxycladon. The Bryologist 100: 359-361.

Robinson, H., and J. Wells. 1956. The bryophytes of certain limestone sinks in Alpena County, Michigan. The Bryologist 59: 12-17.

Schuster, R. M. 1966-1992. The Hepaticae and Anthocerotae of North America east of the hundredth meridian. Vols. I-VI. Columbia University Press, New York.

Stotler, R., and B. Crandall-Stotler. 1977. A checklist of the liverworts and hornworts of North America. The Bryologist 80: 405-428.

Stringer, P. W., and M. H. L. Stringer. 1974a. A quantitative study of corticolous bryophytes in the vicinity of Winnipeg, Manitoba. The Bryologist 77: 551-560.

Stringer, P. W., and M. H. L. Stringer. 1974b. Air pollution and the distribution of epiphytic lichens and bryophytes in Winnipeg, Manitoba. The Bryologist 77: 405-426.

Received 28 November 2011

Accepted 26 January 2012 